\title{
Use of estradiol benzoate to induce ovulation in a short-term protocol for fixed-time $\mathrm{AI}$ in sheep
}

\section{Uso de benzoato de estradiol para induzir ovulação em Protocolo de curta duração para Inseminação Artificial em tempo fixo em ovelhas}

\author{
Caliê Castilho ${ }^{1 *}$; Marcelo Ferreira de Almeida ${ }^{2}$; \\ Ines Cristina Giometti ${ }^{1}$; Marcelo Zoccolaro Costa ${ }^{3}$; \\ Luís Roberto Almeida Gabriel Filho ${ }^{4}$; Angelo Gardim De Cesare ${ }^{3}$
}

\begin{abstract}
The aim of this study was to test the hormonal protocol for fixed-time artificial insemination (TAI) with a progesterone vaginal device for six days applying equine chorionic gonadotropin $(\mathrm{eCG})$ or estradiol benzoate (EB) as an ovulation inducer in ewes. On day $0(\mathrm{D} 0)$, the ewes $(\mathrm{n}=31)$ received a device containing $0.33 \mathrm{~g}$ of intravaginal progesterone $\left(\mathrm{CIDR}^{\circledR}\right)$ and were divided into three groups. The G-CT (control group) used CIDR for nine days and upon withdrawal of the progesterone, were administered prostaglandin F2 alpha (PGF2 $\alpha$ ) and eCG. In the eCG (G-eCG) group, CIDR was administered for six days, instead of nine as in the G-CT group, followed by PGF2a and eCG after progesterone withdrawal. In the EB (G-EB) group, CIDR was also administered for six days, but eCG was not applied, and EB was used to induce ovulation 24 hours after removing the CIDR and PGF2a application. TAI was realized in all groups 50 hours after CIDR withdrawal. The pregnancy rate in the G-eCG group (66.66\%) was higher $(p<0.05)$ than that in the G-EB group $(11.11 \%)$. The short-term groups showed no difference $(p>0.05)$ compared to the G-CT group (30\%). It is possible to reduce the application time of the progesterone and use eCG for TAI in sheep; however, using EB resulted in a low ovulation rate in the sheep.
\end{abstract}

Key words: Ovine CIDR, laparoscopy, ovulation, serum progesterone

\section{Resumo}

O objetivo do presente estudo foi testar protocolo hormonal para inseminação em tempo fixo (IATF) usando dispositivo de progesterona vaginal por seis dias e aplicação de eCG (gonadotrofina coriônica equina) ou BE (benzoato de estradiol) como indutor de ovulação em ovelhas. No dia 0 (D0), as ovelhas $(\mathrm{n}=31)$ receberam CIDR e foram divididas em três grupos. O grupo controle (G-CT) usou CIDR por nove dias e na retirada do dispositivo foi administrado PGF2a e eCG. No grupo eCG (G-eCG), CIDR foi mantido por seis dias, ao invés de nove como no G-CT, com aplicação de PGF2a e eCG na retirada da progesterona. No grupo benzoato de estradiol (G-EB), o CIDR também foi administrado por seis dias, mas não foi utilizado eCG, o BE foi usado para induzir ovulação e foi aplicado 24 horas após a remoção do CIDR e administração de PGF2a. A IATF foi feita em todos os grupos $50 \mathrm{~h}$ após a retirada do CIDR. A taxa de prenhez do G-eCG $(66,66 \%)$ foi maior $(\mathrm{p}<0.05)$ que no G-EB $(11,11 \%)$. O grupo G-eCG de curta duração não diferiu ( $p>0,05)$ do G-CT $(30 \%)$. É possível reduzir o tempo de permanência da progesterona usando eCG para IATF em ovelhas, entretanto o uso de BE resultou em baixa taxa de ovulação.

Palavras-chave: CIDR ovino, laparoscopia, ovulação, progesterona plasmática

\footnotetext{
1 Pesquisadores, Mestrado em Ciência Animal da Universidade do Oeste Paulista, UNOESTE, Presidente Prudente, SP. Brasil. E-mail: calie@unoeste.br; inesgiometti@unoeste.br

2 Discente, Mestrado em Ciência Animal, UNOESTE, Presidente Prudente, SP. Brasil. E-mail: ferreiradealma@gmail.com

3 Médicos veterinários, autônomos, Presidente Prudente, SP. Brasil. E-mail: mzcosta@uol.com.br; acesaree@hotmail.com

4 Pesquisador, Universidade Estadual Paulista Júlio de Mesquita Filho, UNESP, São Paulo, SP. Brasil. E-mail:_lragabrielfilho@ gmail.com

* Author for correspondence
} 


\section{Introduction}

Synchronizing estrus and, thus, ovulation creates an opportunity to use artificial insemination (AI) for groups of ewes with frozen-thawed semen from superior rams and to increase the overall efficiency of genetic improvement programs (CLINE et al., 2001). Traditional treatments for synchronizing ovulation in ewes have consisted of intravaginal sponges containing progesterone for 12 to 14 days (EVANS et al., 2001). Castilho et al. (2013) observed no differences between nine or 14 days of progesterone sponge maintenance for estrous manifestation or pregnancy rates in ewes.

In cattle, estradiol applied concomitantly with the insertion of progesterone-releasing devices induced follicular atresia and the emergence of a new follicular wave after four and a half days (BÓ et al., 1995). However, in the absence of progesterone (removal of the device and luteolysis), estradiol results in ovulation of the dominant follicle in bovines (CASTILHO et al., 2000; FERNANDES et al., 2001). In sheep, estradiol was tested only to induce the follicular wave, which begins approximately 4-6 days after applying the hormone (BARRETT et al., 2008; BARTLEWSKI et al., 2008). Wave emergence was delayed (5.70 vs. $1.4 \mathrm{~d}$ from the time of estradiol injection), and occurred at a predictable time (5-7 d) compared to ewes given medroxyprogesterone acetate (MAP) alone for 0-4 d (BARRETT et al., 2008).

The use of a short-term protocol with a progesterone treatment (5-7 days) before TAI using fresh semen in ewes and goats has been successful (MENCHACA; RUBIANES, 2004). The protocol used in ewes by these authors was performed using intravaginal sponges containing progesterone for seven days in conjunction with two doses of prostaglandin $\mathrm{F} 2$ alpha (PGF2 $\alpha$ ) at sponge insertion and withdrawal. (MENCHACA; RUBIANES, 2004). Fleisch et al. (2013) found a higher overall lambing rate after long-term (12 days) compared to short-term progesterone treatment (6 days) with natural mating. A short-term protocol for TAI with equine chorionic gonadotropin (eCG) or estradiol benzoate (EB) has not been tested in sheep until now. Therefore, the objective of this study was to test the protocol with short-term hormone progesterone (6 days) with TAI using EB or eCG to induce ovulation in sheep.

\section{Material and Methods}

This study was performed in Brazil, in the western part of the state of São Paulo (Latitude $22^{\circ} 07^{\prime} \mathrm{S}$ and Longitude $51^{\circ} 23^{\prime}$ ) in December and January. Thirty-six cross-breed Suffolk primiparous ewes were used, they were 3.0 to 5.0 years old, with a body condition score of 3.0 (scale of 1 to 5). The ewes were kept in Cynodon dactylon (Tifiton 85) and Panicum maximum cv. (Aruana) pastures, and they were supplemented with mineral salt and water ad libitum.

In a random stage of the estrous cycle (day 0), each sheep received a device containing $0.33 \mathrm{~g}$ of intravaginal progesterone (CIDR ${ }^{\circledR}$, Pfizer, Brazil). The following treatments were performed: G-CT (control group, $\mathrm{n}=12$ ) ewes received nine days of CIDR, and at device withdrawal, they received 12 mg of dinoprost (Lutalyse ${ }^{\circledR}$, Pfizer, Brazil) plus 300 IU of eCG (Folligon ${ }^{\circledR}$, Intervet, Brazil). The G-eCG $(n=13)$ and G-EB $(n=13)$ groups had the CIDR removed on day 6 , and all ewes received $12 \mathrm{mg}$ of dinoprost (Lutalyse ${ }^{\circledR}$, Pfizer, Brazil). On the same day, the ewes in the G-eCG group $(\mathrm{n}=13)$ received 300 IU of eCG (Folligon ${ }^{\circledR}$, Intervet, Brazil), while the $\mathrm{G}-\mathrm{EB}$ group $(\mathrm{n}=13)$ received $1 \mathrm{mg}$ of estradiol benzoate (Estrogin ${ }^{\circledR}$, Farmavet, Brazil) 24 hours after removing the CIDR (i.e., on day 7). All hormone injections were given intramuscularly.

At the time of the TAI, the semen was thawed, and the post-thaw motility and forward progressive movement were assessed. Two straws were used, each containing $10 \times 10^{6}$ spermatozoa and averaging $>40 \%$ progressive motility. The ewes were inseminated using a standard laparoscopic 
AI procedure (KILLEN; CAFFERY, 1982) 48 to

50 hours after CIDR removal. Thirty days after the TAI, pregnancy was assessed with transrectal ultrasonography (Aloka SSD500, 5.0 MHz, Japan).

The blood samples were collected on the following days: D0 (CIDR inserted in three groups); D6 for G-EB and G-eCG and D9 for G-CT (corresponding to the days of CIDR removal); D7 for G-EB and G-eCG and D10 for G-CT (24 hours after the PGF2 $\alpha$ application); and D17 for G-EB and G-eCG and D20 for G-CT (9 days after TAI to assess the ovulation rate). Approximately $10 \mathrm{~mL}$ of blood was collected from the jugular vein and placed in heparinized tubes; the plasma was separated using centrifugation and stored at $-20{ }^{\circ} \mathrm{C}$ until it was assayed. The progesterone concentrations were quantified by performing RIA using an RIA kit (Coat-a-Count; Diagnostic Products Corporation, Los Angeles, CA, USA). The assay sensitivity was $0.0049 \mathrm{ng} / \mathrm{mL}$; the intra-assay coefficient of the high control was $10.02 \%$, and the low control variation was $0.31 \%$.
The statistical analyses were performed using Fisher's exact test for the differences between groups for the pregnancy rates. The average serum concentrations of progesterone between the groups were compared using an analysis of variance (ANOVA), with contrasts using Tukey's test and different moments within each group using the ANOVA test for the paired data. The level of significance was 5\% (PAGANO; GAUVREAU, 2004).

\section{Results and Discussion}

This experiment began with 36 animals; however, five of the animals (13.89\%) lost the intravaginal CIDR during the progesterone treatment. Thus, 31 animals remained in the experiment. Table 1 shows the number and percentage of the pregnant animals in the G-CT, G-eCG and G-EB groups. There was a significant difference in the pregnancy rate, which was significantly higher $(p=0.0244)$ in the G-eCG group $(66.66 \%)$ than in the G-EB group $(11.11 \%)$.

Table 1. Percentage, number of pregnancies and p-value obtained from the comparison of groups of sheep subjected to synchronization of estrus protocols using CIDR for 9 days $(\mathrm{G}-\mathrm{C} T$ control, $\mathrm{n}=10)$ or for 6 days $(\mathrm{G}-\mathrm{eCG}, \mathrm{n}=12$; $\mathrm{G}-\mathrm{EB}, \mathrm{n}=9$ ) for TAI.

\begin{tabular}{ccc}
\hline Treatments & \% Pregnancy & p-values \\
\hline G-CT & $30.00 \%(3 / 10) \mathrm{ab}$ & vs $\mathbf{G}-\mathbf{e C G}(\mathbf{p}=\mathbf{0 . 1 1 4 2})$ \\
G-eCG & $66.66 \%(8 / 12) \mathrm{a}$ & vs $\mathbf{G}-\mathbf{E B}(\mathbf{p}=\mathbf{0 . 0 2 4 4})$ \\
G-EB & $11.11 \%(1 / 9) \mathrm{b}$ & vs $\mathbf{G}-\mathbf{C T}(\mathbf{p}=\mathbf{0 . 5 8 2 0})$ \\
\hline
\end{tabular}

G-CT = CIDR for nine days and PGF2 $\alpha$ and eCG application; G-eCG = CIDR for six days and PGF2 $\alpha$ and eCG application; G-EB $=$ CIDR for six days, PGF2 $\alpha$ application and EB injection 24 hours later. Different letters differ within the column $(\mathrm{p}<0.05)$.

Source: Elaboration of the authors.

Of all the progesterone samples that were obtained from day $0(n=27)$, only one animal showed concentrations $<1 \mathrm{ng} / \mathrm{mL}$, and of the samples taken 24 hours after applying PGF2a $(n=30)$, only four samples showed progesterone levels $>2 \mathrm{ng} /$ $\mathrm{mL}$. The progesterone levels that were assessed nine days after the TAI showed that the G-CT and G-eCG groups (in all of the samples) exhibited progesterone levels $>3 \mathrm{ng} / \mathrm{mL}$, whereas in the G-EB group, four of the nine samples $(44.44 \%)$ were $<2$ ng/mL (Table 2). 
Table 2. Mean \pm standard deviations of the serum progesterone on days: D0; D6 or D9, corresponding to the moment of implant withdrawal; 24 hours after PGF2a injection, day 7 or 10, and 9 days after TAI on day 17 or 20.

\begin{tabular}{ccccc}
\hline Groups & D0 & D6 or 9 & D7 or 10 & D17 or 20 \\
\hline G-CT & $6.58 \mathrm{Aa} \pm 4.05$ & $6.03 \mathrm{Aa} \pm 3.89$ & $0.81 \mathrm{Ab} \pm 0.41$ & $6.38 \mathrm{Aa} \pm 2.21$ \\
G-eCG & $5.24 \mathrm{Aa} \pm 3.27$ & $5.01 \mathrm{Aab} \pm 0.983$ & $1.35 \mathrm{Ab} \pm 1.43$ & $5.64 \mathrm{Aa} \pm 2.99$ \\
G-EB & $5.85 \mathrm{Aa} \pm 3.57$ & $4.08 \mathrm{Aab} \pm 1.00$ & $1.27 \mathrm{Ac} \pm 0.69$ & $2.20 \mathrm{Bbc} \pm 2.13$ \\
\hline
\end{tabular}

$\mathrm{G}-\mathrm{CT}=\mathrm{CIDR}$ for nine days and PGF2 $\alpha$ and eCG application; G-eCG = CIDR for six days and PGF2 $\alpha$ and eCG application; G-EB $=$ CIDR for six days, PGF2 $\alpha$ application and EB injection 24 hours later. Values in the same row followed by the same lowercase letters are not statistically different $(\mathrm{p}>0.05)$. Values in the same column followed by the same uppercase letters are not statistically different.

Source: Elaboration of the authors.

The experiment was conducted during the months of December and January, a time of transition in the southern hemisphere, during which some animals begin to exit the seasonal anestrus. Sheep exhibit reproductive seasonality that is characterized by cycles, usually appearing in summer or early fall and ending in late winter or early spring (ORTAVANT et al., 1985). The pregnancy rate in the G-eCG group was higher than that in the G-EB group and was not different $(p>0.05)$ from that of the G-CT group. The decrease in the time of exposure to progesterone from 9 to 6 days did not affect the results; the group with 6 days of exposure was statistically equal to the control (9 days) and numerically greater $(66.6 \mathrm{x}$ $30.0 \%$ ). This result was promising because reducing the CIDR residence time allowed it to be re-used, thereby reducing the protocol cost. Implementing EB instead of eCG was ineffective and resulted in a low pregnancy rate. The drug choice (EB) was based on its low cost and also because of its routine use in successful TAI protocols in cows (inducing the preovulatory peak of LH) (CASTILHO et al., 2000). One hypothesis for this result was that the females were in seasonal anestrous, and applying EB induced an increase in the estradiol negative feedback to the hypothalamus and pituitary. However, 96.3\% (1/27) of the females showed progesterone values $>2 \mathrm{ng} /$ $\mathrm{ml}$, which indicated cyclicity. The EB appeared to have blocked ovulation; $44.4 \%$ (4/9) of the ewes did not ovulate in that group; instead, they showed subluteal progesterone $(\downarrow 2 \mathrm{ng} / \mathrm{ml})$ levels nine days after the TAI. In the G-CT and G-eCG groups, $100 \%$ of the ewe's serum progesterone was $>3 \mathrm{ng} / \mathrm{ml}$ over the same period. The results showed that 24 hours after applying PGF $2 \alpha, 86.66 \%$ (4/30) of the progesterone samples exhibited concentrations $<2 \mathrm{ng} / \mathrm{mL}$, and in the G-EB group, only one animal exhibited a concentration of $2.56 \mathrm{ng} / \mathrm{ml}$; all the other animals had concentrations $<2 \mathrm{ng} / \mathrm{mL}$, which indicated that PGF2a was effective in promoting luteolysis. Estrus does not occur until the P4 levels decline to approximately $1 \mathrm{ng} / \mathrm{mL}$ (STABENFELDT; HOLT; EWING, 1969; JOHNSON et al. 1996). In this study, the pregnancy rate after laparoscopic AI ranged from $11.1 \%$ to $66.6 \%$. This variation was likely caused by the protocol used because the AIs were performed by a single technician with several years of experience.

We conclude that it is possible to use a progesterone implant for a short time period (6 days) and to use eCG for ovulation induction without affecting the pregnancy rate. However, using EB resulted in a decreased ovulation rate.

\section{Acknowledgement}

The authors are grateful for financial support from Pfizer Brazil for CIDR devices and PGF2 $\alpha$ and from the Universidade do Oeste Paulista (UNOESTE).

This research was approved by the Ethics Committee of the institution of origin (UNOESTE), filed under $\mathrm{n}^{\mathrm{o}}$ 081/07. 


\section{References}

BARRETT,D.M.;BARTLEWSKI,P.M.;DUGGAVATHI, R.; DAVIES, K. L.; HUCHKOWSKY, S. L.; EPP, T.; RAWLINGS, N. C. Synchronization of follicular wave emergence in the seasonally anestrous ewe: the effects of estradiol with or without medroxyprogesterone acetate. Theriogenology, Stoneham, v. 69, n. 7, p. 827-36, 2008.

BARTLEWSKI, P. M.; ALEXANDER, B. D.; RAWLINGS, N. C.; BARRETT, D. M.; KING, W. A. Ovarian responses, hormonal profiles and embryo yields in anoestrous ewes superovulated with Folltropin $\mathbb{R}-\mathrm{V}$ after pretreatment with medroxyprogesterone acetatereleasing vaginal sponges and a single dose of oestradiol17ß. Reproduction in Domestic Animals, Berlin, v. 43, n. 3, p. 299-307, 2008.

BÓ, G. A.; ADAMS, G. P.; CACCIA, M.; MARTINEZ, M.; PIERSON, R. A.; MAPLETOFT, R. J.; Ovarian follicular wave emergence after treatment with progesterone and estradiol in cattle. Animal Reproduction Science, Amsterdam, v. 39, n. 3, p. 193-204, 1995.

CASTILHO, C.; ALMEIDA, M. F.; COSTA, M. Z.; DE CESARE, A. G.; GABRIEL FILHO, L. R. A. Protocolos de indução e sincronização do estro em ovelhas. Ciência Animal Brasileira, Goiânia, v. 14, n. 1, p. 91-97, 2013.

CASTILHO, C.; GAMBINI, A. L. G.; FERNANDES, P. ; TRINCA, L. A.; TEIXEIRA, A. B.; BARROS, C. M. Synchronization of ovulation in crossbred dairy heifers using gonadotrophin-releasing hormone agonist, prostaglandin F2a and human chorionic gonadotrophin or estradiol benzoate. Brazilian Journal of Medical and Biological Research, Ribeirão Preto, v. 33, n. 1, p. 91101, 2000.

CLINE, M. A.; RALSTON, J. N.; SEALS, R. C.; LEWIS, G. S. Intervals from norgestomet withdrawal and injection of equine chorionic gonadotropin or P. G. 600 to estrus and ovulation in ewes. Journal of Animal Science, Champaign, v. 79, n. 3, p. 589-594, 2001.
EVANS, A. C. O.; FLYNN, J. D.; QUINN, K. M.; DUFFY, P.; QUINN, P.; MADGWICK, S.; CROSBY, T. F.; BOLAND, M. P.; BEARD, A. P. Ovulation of aged follicles does not affect embryo quality or fertility after a 14-day progestagen estrous synchronization protocol in ewes. Theriogenology, Los Altos, v. 56, n. 5, p. 923-936, 2001.

FERNANDES, P.; TEIXEIRA, A. B.; CROCCI, A. J.; BARROS, C. M. Timed artificial insemination in beef cattle using GnRH agonist PGF2alpha and estradiol benzoate. Theriogenology, Los Altos, v. 55, n. 7, p. 15211532, 2001.

FLEISCH, A.; PIECHOTTA, M.; BOLLWEIN, H.; JANETT, F. Fertility after treatment with Eazi-breedTM CIDR $\mathrm{G}$ for 6 or 12 days outside the breeding season in Lacaune dairy sheep. Schweizer Archiv für Tierheilkund, Zurich, v. 155, v. 7, p. 391-398, 2013.

JOHNSON, S. K.; DAILEY, R. A.; INSKEEP, E. K.; LEWIS, P. E. Effect of peripheral concentrations of progesterone on follicular growth and fertility in ewes. Domestic Animal Endocrinology, Stoneham, v. 13, n. 1, p. 69-79, 1996.

KILLEN, I. D.; CAFFERY, G. J. Uterine insemination of ewes with the aid of a laparoscope. Australian Veterinary Journal, Oxford, v. 59, n. 3, p. 95, 1982.

MENCHACA, A.; RUBIANES, E. New treatments associated with timed artificial insemination in small ruminants. Reproduction, Fertility and Development, East Melbourne, v. 16, n. 4, p. 403-414, 2004.

ORTAVANT, R.; PELLETIER, J.; RAVAAULT, J. P.; THIMONIER, J.; VOLLNAD-NAIL, P. Photoperiod, main proximal and distal factor of distal factor of the circannual cycle of reproduction in animal. Oxford Reviews of Reproductive Biology, Oxford, v. 7, p. 305345, 1985.

PAGANO, M.; GAUVREAU, K. Princípios de bioestatística. Thompson Learneing. $2^{\text {th }}$ ed. São Paulo: Pioneira, 2004. 506 p.

STABENFELDT, G. H.; HOLT, J. A.; EWING, L. L. Peripheral plasma progesterone levels during the ovine estrous cycle. Endocrinology, Chevy Chase, v. 85, n. 1, p. 11-15, 1969. 
